\title{
Predilection of Teaching Aids Among Year I Medical Students at a Medical College of Mauritius
}

\author{
Barun Mahat ${ }^{1}$, Prakash Limbu ${ }^{2}$, Indrajit Banerjee ${ }^{3}$,Sunil Dhungel ${ }^{2}$ and Pawan Kumar Lal Das ${ }^{4}$ \\ ${ }^{1}$ Department of Physiology, SSR Medical College, Belle Rive, Mauritius, ${ }^{3}$ Department of \\ Pharmacology, SSR Medical College, Belle Rive, Mauritius, 2Department of Clinical Physiology, \\ Nepalese Army Institute of Health Sciences, Kathmandu, Nepal, ${ }^{4}$ Department of Physiology, KIST \\ Medical College, Kathmandu, Nepal.
}

\section{ABSTRACT}

Introduction: Teaching aids are the motivational tool which plays an important role in teaching and learning processes in such a way that it makes the classroom lively, active and interactive. It creates an environment of interest for the students as well as it helps to clarify and understand the subject matter in a better way. The objective of this study is to know the opinion of students regarding the teaching aids among $1^{\text {st }}$ year MBBS students during teaching and learning activities in physiology at SSR Medical College.

Methods: The data were collected by pre-designed questionnaire among the $1^{\text {st }}$ year MBBS students of SSR Medical College, Belle Rive, Mauritius. The study was conducted between March and April, 2016. Out of 147 students, 139 students were participated in the study. The data were analyzed using nonparametric test and $\mathrm{P}$ values were analyzed by using Chi-Square test. $\mathrm{P}<0.05$ was considered significant.

Results: $60.4 \%$ of students thought that the combination of black board and PowerPoint slides was more beneficial compared to blackboard, PowerPoint and whiteboard which were selected by $24.5 \%$, $14.4 \%$ and $0.7 \%$ respectively. The combination of blackboard and Power Point slides was selected as the most understandable and informative by $51.8 \%$ and $64 \%$ students respectively. Similarly, the same teaching method was considered the most helpful in retention by $48.2 \%$ respondents and most emphatic on important points by $47.5 \%$. More than $50 \%$ of the students found the combination of blackboard and Power Point slides as the most captivating (55.4\%), interactive (57.6\%), providing excellent visual clarity $(56.8 \%)$, easy for summarization $(51.1 \%)$ and effective for presentation (56.8\%). $46 \%$ of the students thought that this combination of teaching aid covered the more topic per lecture.

Conclusion: This study shows that the majority of the students preferred combination of aids viz. black board and Power Point for learning and teaching physiology.

Keywords: teaching and learning activities; teaching aids; preference; mauritius

\section{INTRODUCTION}

Human physiology is one of the most important subjects in medical education. It tells us about the functions of various systems of the body and how they work in integrated way so as to maintain the homeostasis of the body. ${ }^{1}$ The teaching aids play important role in teaching and learning processes. It is the back bone of education, makes teaching and learning more interesting as well as it provides good interaction between teachers and students. ${ }^{2}$
This work is licensed under: http:// creativecommons.org/licenses/by-nc-nd/4.0/

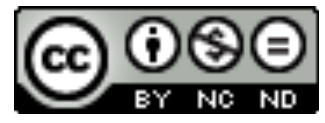

Correspondence: Barun Mahat, Department of Physiology, Nepalese Army Institute of Health Sciences, Kathmandu, Nepal. Email: barun.mahat@hotmail.com 
Nowadays teaching and learning have been moving toward the student-centred learning rather than teacher-centred learning. ${ }^{3}$ Teaching aid is the essential tool for transferring knowledge from teachers to students, for helping to improve the quality of education and for creating learning environment to the students. ${ }^{4}$ The various teaching aids on practice are traditional chalk blackboard, overhead projector, Power Point slides. ${ }^{5}$ Utilization of teaching aids has been changing due to ongoing development of new technology and their adaptation has been dependent on user's knowledge towards the recent technology. ${ }^{6}$ Therefore, it is the responsibility of the teacher to modify and select the best teaching method; initiate an idea to make teaching more interesting, inspiring and creative; synthesize in such a way that the students become able to reproduce information when it is needed; and help improve the academic performance. ${ }^{7,8}$

This is the first study conducted in Mauritius about the teaching aids used in physiology for teaching and learning activities at SSR Medical College, Mauritius. The best way to assess and improve the teaching and learning activities is through the student's feedback. Therefore, the aim of this study is to know the opinion of students regarding the preference of teaching aids.

\section{METHODS}

This is a cross- sectional questionnaire based study conducted among 147 first year MBBS students who were attending lecture and tutorial classes in the department of physiology at SSR Medical College, Mauritius. Established in 1996 by the Indian Ocean Medial Trust, SSR Medical College is the first medical college in Mauritius, and it is affiliated to the University of Mauritius. It admits students mainly from India, South Africa and Mauritius. The study was conducted in between March and April, 2016.

Out of 147 students, we got a sample of 139; four were drop outs from the course and eight were absent from the classes at time of collecting data. The overall response rate of the questionnaire was $99.55 \%$. After taking verbal consent, questionnaires comprised of twelve different questions were distributed among students. The questionnaire was made to assess the attitude of students regarding teaching aids. All the students were instructed to select suitable options (teaching aids) for each of twelve questions with their own knowledge and were assured that their preference would be kept confidential. The results were analyzed by nonparametric test using SPSS Version 20. P value were analyzed by using Chi-Square test. $\mathrm{P}<0.05$ was considered significant. Prior to the study, ethical committee approval was taken from the institutional ethical committee. The Research was conducted in accordance to latest version of the Declaration of Helsinki.

\section{RESULTS}

In the response to which teaching method was most understandable, combination of blackboard and PowerPoint slides was chosen by $51.8 \%$, PowerPoint by $30 \%$, blackboard by $18 \%$ and whiteboard by none. Similarly, in regard to the teaching method which imparts more knowledge, combination of blackboard and Power Point slides was clearly superior with $64 \%$ students compared to Power Point, blackboard and whiteboard, which were preferred by $18.7 \%, 16.5 \%$ and $0.7 \%$ of students respectively. It observed that the combination of blackboard and Power Point slides was the best method for retention of subject matter and for giving more emphasis on important points with $48.2 \%$ and $47.5 \%$ students opting this method for these attributes. In contrast, blackboard was chosen only by $27.3 \%$ and $28.1 \%$ as the method of preference for retention of subject matter and giving more stress on important points, PowerPoint by $18.7 \%$ and $18.7 \%$ and whiteboard by $5.8 \%$ and $5.8 \%$. This study also found that taking notes and diagrams were also easier with combination of blackboard and Power Point slides with $43.9 \%$ compared to blackboard $27.3 \%$, Power Point slides $23.7 \%$ and whiteboard 5\%.

In this study, it was noticed that $55.4 \%$ and $57.6 \%$ students selected the combination of blackboard and Power Point slides as the most captivating and interactive method during physiology lecture. With respect to most captivating and interactive method, Power Point was chosen by $23.7 \%$ and $15.1 \%$ students, black board by $16.5 \%$ and $25.2 \%$ students, and whiteboard by $4.3 \%$ and $2.2 \%$ respondents. This study found that $56.8 \%$ students believed the combination of blackboard and Power Point slides was the method with the most excellent visual clarity in comparison to the Power Point slides with $33.8 \%$, blackboard with $7.2 \%$ and whiteboard with $2.2 \%$. In addition, in terms of 


\begin{tabular}{|c|c|c|c|c|}
\hline Parameters & $\begin{array}{c}\text { Black Board } \\
\text { N }(\%)\end{array}$ & $\begin{array}{l}\text { Power Point } \\
\text { N }(\%)\end{array}$ & $\begin{array}{c}\text { Combined } \\
\text { (Black Board \& Power Point } \\
\text { N }(\%)\end{array}$ & $\begin{array}{l}\text { White Board } \\
\text { N }(\%)\end{array}$ \\
\hline Beneficial & $34(24.5)$ & $20(14.4)$ & $84(60.4)$ & $1(0.7)$ \\
\hline Easy to follow \& understandable & $25(18)$ & $42(30.2)$ & $72(51.8)$ & - \\
\hline informative, knowledge, concept & $23(16.5)$ & $26(18.7)$ & $89(64)$ & $1(0.7)$ \\
\hline Retention \& consolidation & $38(27.3)$ & $26(18.7)$ & $67(48.2)$ & $8(5.8)$ \\
\hline $\begin{array}{l}\text { Helpful in stressing on important } \\
\text { points }\end{array}$ & $39(28.1)$ & $26(18.7)$ & $66(47.5)$ & $8(5.8)$ \\
\hline Taking notes, diagrams, charts & $38(27.3)$ & $33(23.7)$ & $61(43.9)$ & $7(5.0)$ \\
\hline Topic per lecture coverage & $19(13.7)$ & $50(36)$ & $64(46)$ & $6(4.3)$ \\
\hline Impact on presentation & $28(20.1)$ & $26(18.7)$ & $79(56.8)$ & $6(4.3)$ \\
\hline Interactive & $35(25.2)$ & $21(15.1)$ & $80(57.6)$ & $3(2.2)$ \\
\hline Captivating & $23(16.5)$ & $33(23.7)$ & $77(55.4)$ & $6(4.3)$ \\
\hline Easily summarized & $18(12.9)$ & $45(32.4)$ & $71(51.1)$ & $5(3.6)$ \\
\hline Excellent visual clarity & $10(7.2)$ & $47(33.8)$ & $79(56.8)$ & $3(2.2)$ \\
\hline
\end{tabular}

coverage of topic per lecture and easy summarization of subject matter, combination of blackboard and Power Point was chosen as the best method with $46 \%$ and $51.1 \%$ students, followed by Power Point with $36 \%$ and $32.4 \%$, blackboard with $13.7 \%$ and $12.9 \%$, and whiteboard with $4.3 \%$ and $3.6 \%$.

This study found that $60.4 \%$ of students thought that combination of blackboard and PowerPoint was more beneficial compared to blackboard, PowerPoint and whiteboard which were selected by $24.5 \%, 14.4 \%$ and $0.7 \%$ respectively. It was also found out that $56.8 \%$ students chose the combination of blackboard and Power Point as the method having highest impact on presentation during physiology lecture. This was followed by blackboard at $20.1 \%$, Power Point at $18.7 \%$ and whiteboard at $4.3 \%$. All the results mentioned here are statistically significant as show in Table 1

\section{DISCUSSION}

\section{Student's accreditation regarding various teaching aids in physiology}

In modern era, along with the development and expansion of various teaching aids, the qualities of teaching and learning activities as well as the outcome of students in terms of their performance in examination have been improving. The students take more responsibility for their own learning, while teachers just act as facilitators, evaluators, planners and resource developers. Empowering teaching and learning is challenging and complex. The teaching aids make learning easy to follow and understand. In this study, it was observed that understanding the topic per lecture is best provided with combination of black board and Power Point. The study conducted by Purushottam A G et al. and Shridevi et al. found that the combination of these aids was best in regards of understanding the topics. ${ }^{9,10}$ Insufficiency of one aid can be compensated by the other. This finding is parallel to the study conducted by Banerjee I et al at Nepal. ${ }^{11}$ However, the finding of this study in terms of teaching aid preference is different from the study conducted by Banerjee I et al in Kathmandu, Nepal, which reported that 'Chalk and Board' was the best method of teaching and learning. ${ }^{12,}{ }^{13}$ In this study, the main reason of liking the combination of black board and Power Point could be due to the fact that it allows adequate time for students to take notes and to stress on important points. Skandhan KP et 
al. and Saha N et al. also observed the similar reasons for preferring the combination of blackboard and Power Point slides. ${ }^{14,15}$

\section{Impact of Combination of Teaching AIDS in Physiology}

Academic performance of the students is influenced by the knowledge, concepts of subjects as well as retention and consolidation of memory of the subject matter. According to this study, majority of the students preferred combination of black board and Power Point for gaining information and concepts. Similarly, about half of the respondents considered these combination as the most suitable method for retention and consolidation of the lecture.

The classes and learning process are competitive and individualistic. The quality of outcome can be improved by interaction between the faculty members and students regarding topics and making the lecture captivating with excellent visual and verbal clarity. In this study, majority of students mentioned that the combination of these aids as most interactive $(57.6 \%)$, captivating $(55.4 \%)$ and provided the best visual clarity $(56.8 \%)$. Similarly, the study carried out by Chadhary $\mathrm{R}$ et al and Mukut $\mathrm{R}$ et al also found that the combination of teaching aid as the most preferable means of teaching in terms of interaction, interest arousal and clarity. ${ }^{16,17}$

This study revealed that $60.4 \%$ and $56.8 \%$ of students thought the combination of blackboard and Power Point slides as the most beneficial and provided the most excellent impact on presentation in teaching and learning activities. The studies conducted by Mohan L et al and Purushottam A G et al reported similar results, in which $42.4 \%$ and $51.2 \%$ of the students chose this combination of teaching aids as beneficial and effective in giving lecture. ${ }^{18,9}$ According to this study, $51.1 \%$ of students thought the combination of aids was superior for summarization and $46 \%$ believed that it was the best for covering topic per lecture within time provided. The study conducted by Shaguphta $\mathrm{T} \mathrm{S}$ also revealed that coverage of topic per lecture and summarization of lecture were better by using the combination of audio-visual aids than by using other means. ${ }^{19}$ Therefore, teaching and learning activities can be enhanced by proper blending of lecture and teaching aids.

\section{CONCLUSIONS}

This study shows that majority of the students preferred combination of aids viz. black board and Power Point for learning physiology because insufficiency of one aid can be fulfilled by the other and offers best opportunities for learning, such as taking notes, diagrams, understanding concepts, retaining knowledge and various activities involved in teaching and learning physiology.

\section{REFERENCES}

1. Guyton and Hall. Text Book of Medical Physiology. Introduction of Physology: The Cells and General Physiology: Sunder Elsevier; 2006 print.

2. Brown G, Manogue M. AMEE Medical Education Guide No.22: Refreshing lecturing: A guide for lecturer. Med. Teach2001; 23(3):231-44. http://dx.doi.org/ 10.1080/01421590120043000

3. Schaefer KM, Zygmont D. Analysing the teaching style faculty. Does it promote a student-centered or teacher-centered learning environment? Nurs Edu Prespect. 2003sep-oct;24(5):238-45

4. Papanna km, Kulkami V, Tanvi D et al. Preceptions and preferences of medical students regarding teaching methods in a Medical College, Mangalore, India. Afr. Health Sci. 2013 sep; 13(3):808-13. DOI:10.4314/ ahs.v13i3.41

5. Sethi V, Upadhyaya P, Ahmad M, Moqhe V. Power Point or chalk and talk: Preceptions of medical students verus dental students in a medical college in India. Adv Med Edu Pract.2010Aug30; 1:11-6. DOI:10.2147/ AMEP.S12154

6. Jadhav V S, Adchtre S A, Magare A R, Surve R et al. A comparative study of blackboard teaching with powerpoint teaching in third year medical students.AJCMAAS.2016June, 11(1);17-21.Logic Publications@2016, IJCMAAS, E-ISSN: 2321-9335,PISSN:2321-9327

7. Kyle BM, Corral I, John NJ, Shelton PG. Eductional scholarship and technology: Resources for a changing undergraduate medical education curriculum. Psychatr Q.2016 oct 26. [Epub ahead of print] . DOI: $10.1007 /$ s11126-016-9474-7

8. Waheeda S, Sathiya M K. A comparative study of black board teaching with Power Point teaching in 1 year medical students. NJBMS.2015Jul-Sept; 6(1): 11-13. Online ISSN no.2455-1740

9. Purushottam A G, Deepak B P DB. Views regarding use of audio-visual aids during didactic lectures in community medicine among first year medical students of Rural Medical College, Loni, Maharashtra. NJRC. 
2013Jul- Sep; 2(2):079-148. ISSN - Print: 2277 - 1522,

Online: 2277 - 3517

10. Shridevi A S, Guyatri L P, Arif N K. et al.Role of audio-visual aids as a teaching and learning method for understanding mechanism of labor. J Pub Health Med Res 2013;1(2): 97-99

11. Banerjee I, Roy B , Sathian B , Pugazhandhi B, Saha A , Banerjee I . Teaching Aids in Pharmacology Teaching and Learning Methodology: A Study from a Medical College of Nepal. IJIMS. 2013;Vol 1(1):1-7. Available online at http://www.ijims.com

12. Banerjee I, Jauhari A C, Bista D, Johorey A C, Roy B, Sathian B. Medical Students View about the Integrated MBBS Course: A Questionnaire Based Cross-sectional Survey from a Medical College of Kathmandu Valley. Nepal Journal of Epidemiology 2011;1(3): 95-100. DOI: http://dx.doi.org/10.3126/ nje.v1i3.5575

13. Banerjee I, Jauhari CA, Johorey CA, Gyawali S, Saha A. Student's Accreditation of integrated Medical Education in Nepal.AJMS.2011;2(1):49-52.DOI: 10.3126/ajms.v2i1.3592

14. Skandhan KP, Dilroop D, Abhai SPS. Teaching physiology: Undergraduates' prespective.IOSR-JRME. 2013May-June;5(3):2-85.DOI:109790/7388-05338255

15. Saha N, Tripura K, Das R. Students'opinion towards audio-visual aids used in lecture classes. IOSR-JDMS. 2015Apr; 14(4):96-100.

16. Chaudry R, Dullo P, Gupta U. Attitude of 1st MBBS medical students about two different visual aids in physilology lectures. Pak J Physiol 2009; 5(2): 16-19.http://www.pps.org.pk/PJP/5-2/Chaudary.pdf

17. Mukut R, Nirmalya S. Medical students and the use of mixed audio-visual aids in lecture classes. IOSRJ D M S 2015 Dec;14(12):6-70.http:// www.iosrjournals.orgDOI: 10.9790/0853-141256870

18. Mohan L, Ravi Shankar P, Kamath A, Manish MS, Eesha BR. Students' attitude towards the use of audio visual aids during didactic lectures in pharmacology. JCDR.2010Dec ; 4):3363-3368.http://www.jcdr.in/ article_fulltext.asp?issn $=0973-709 x \& y$ ear $=2010 \&$ volume $=4$ \&issue $=6$ \& page $=3363-3368 \&$ issn=0973- 709x \& id=XXX

19. Shaguphta $\mathrm{T}$ Teaching learning aids in medical education. The student's perspective. Int J Clin Surg Adv 2015; 3(1):-32-37. 